\title{
Alat permainan edukatif berbasis lingkungan untuk pembelajaran saintifik tema lingkungan bagi guru paud korban gempa
}

\author{
Baik Nilawati Astini, Nurhasanah, Hayatun Nupus
}

Universitas Mataram. Jl. Majapahit No.62, Gomong, Kota Mataram, Nusa Tenggara Bar. 83115, Indonesia email: nilaastini@ymail.com, nurhasanah@unram.ac.id, nupus13@gmail.com

\begin{tabular}{l}
\hline ARTICLE INFO \\
\hline \hline Article history: \\
Received: $20-8-2019 ;$ \\
Revised: $21-8-2019 ;$ \\
Accepted: $21-8-2019$ \\
Keywords: \\
APE; Pembelajaran \\
Saintifik; Educational \\
Games; Scientific Learning
\end{tabular}

\section{ABSTRACT}

Penelitian ini bertujuan untuk pengembangan APE berbasis lingkungan pada tema lingkungan untuk pembelajaran saintifik bagi guru-guru korban gempa di Kecamatan Tanjung Kabupaten Lombok Utara. Penelitian ini adalah penelitian action research. Populasi dari penelitian ini yakni seluruh guru korban gempa yang ada di Kecamatan Tanjung dan Sampel penelitian ini yakni 20\% dari jumlah populasi yang ada yang akan dipilih secara random yakni sebanyak 38 orang guru. Teknik pengumpulan data menggunakan metode pengisian angket, FGD (Fokus Group Diskusi) dan dokumen. Data yang diperoleh dianalisis menggunakan metode analisis deskriptif kualitatif. Hasil penelitian ini adalah terbentuknya model pengembangan APE berbasis lingkungan untuk pembelajaran saintifik pada tema lingkungan dapat dilakukan dengan beberapa tahapan yakni identifikasi sumber bahan pembuatan APE berbasis lingkungan untuk pembelajaran saintifik pada tema lingkungan, penglompokkan bahan pembuatan APE berbasis lingkungan untuk pembelajaran saintifik pada tema lingkungan, mengembangkan APE berdasarkan pengelompokkan, dan tercipta APE untuk pembelajaran saintifik pada tema lingkungan. Bentuk-bentuk APE yang dapat dikembangkan untuk pembelajaran saintifik yakni bentuk miniatur rumah, bentuk perahu, bentuk mobilmobilan, bentuk orang-orangan dari pelepah pisang, kertas dan kardus bekas, bentuk ikan dari kertas origami dan bentuk pohon angka dari ranting pohon kering dan angka berbentuk buah apel yang diberi tulisan angka. Dan kelompokkelompok APE dibagi menjadi dua kelompok APE dengan jenis main peran mikro dan jenis main pembangunan. Dari hasil penelitian ini guru dapat memanfaatkan bahan-bahan yang ada dilingkungan sekitar untuk membuat APE dan dapat menjadi acuan bagi guru dalam meningkatkan kreatifitas dalam mengembangkan APE.

This study aims to develop an environment-based Educational Game for scientific learning on environmental themes for teachers who were earthquake victims in Tanjung Subdistrict, North Lombok Regency. This is action research. The population of this study consisted of all teachers who were the earthquake victims in Tanjung Subdistrict and $20 \%$ of the total population (38 teachers) was then randomly selected as the sample of the study. The data were collected by means of questionnaire, FGD (Focus Group Discussion), and documentation. The data were then analyzed using the qualitative descriptive analysis method. The results of this study shows that the development of the environment based Educational Game can be done in several stages: (1) identifying material sources, (2) grouping the materials, (3) developing the educational game based on the grouping, and (4) developing the Educational Game for scientific learning on environmental themes. The educational game that can be developed for scientific learning involves miniature houses, boat shapes, car shapes, scarecrow shapes, used paper and cardboard, fish shapes from origami paper and tree in number shapes from dry branches and apple shaped numbers. The game was classified into two types, i.e. micro role play and building play. From the results of this study the teacher can utilize existing materials in the surrounding environment to develop educational games. Teachers could also refer to this study in developing creative educational games. 
Baik Nilawati Astini, Nurhasanah, Hayatun Nupus

\section{PENDAHULUAN}

Latif (2013) dalam Undang-Undang Sistem Pendidikan Nasional No. 20 Tahun 2003 Pasal I ayat 14 yang menyatakan bahwa Pendidikan Anak Usia Dini (PAUD) adalah suatu upaya pembinaan yang ditujukan bagi anak sejak lahir sampai dengan usia enam tahun yang dilakukan melalui pemberian rangsangan pendidikan untuk membantu pertumbuhan dan perkembangan jasmani dan rohani agar anak memiliki kesiapan dalam memasuki pendidikan yang lebih lanjut, yang diselenggarakan pada jalur formal, nonformal, dan informal.

Susanto (2015, p. 93), mengungkapkan bahwa pendidikan pada anak usia dini dilakukan dengan pembelajaran melalui bermain. Dimana melalui bermain, anak diajak untuk bereksplorasi untuk mengenal lingkungan sekitar, menemukan dan memanfaatkan objek-objek yang dekat dengan anak, sehingga pembelajaran menjadi bermakna bagi anak.

Belajar sambil bermain, pendidik membutuhkan sebuah Alat Permainan Edukatif (APE) untuk diajarkan kepada anak. Alat Permainan Edukatif (APE) adalah sebuah media yang dirancang dan dibuat untuk membantu proses belajar mengajar pendidik di kelas serta dapat membantu peserta didik untuk mengembangkan potensi yang ada dalam dirinya. Alat Permainan Edukatif (APE) adalah alat permainan yang dapat dibuat dengan berbagai macam bahan seperti bahan yang ada di lingkungan yang dapat kita sebut juga APE berbasis lingkungan. Alat Permainan Edukatif (APE) berbasis lingkungan adalah APE yang dibuat dengan bahan-bahan yang dimanfaatkan dari lingkungan sekitar sehingga dapat memudahkan pendidik untuk membuatnya dengan berbagai bentuk, jenis-jenisnya yang memiliki manfaat untuk menarik minat anak belajar, anak memiliki pengalaman baru dan lebih cepat dalam menangkap pembelajaran serta membantu dalam proses pembelajaran saintifik. Pembelajaran saintifik adalah suatu pembelajaran yang terfokus pada peserta didik dan anak lebih aktif melakukan sesuatu. Berdasarkan hal-hal tersebut, maka dengan kondisi saat ini di pulau Lombok, Nusa Tenggara Barat (NTB) tepatnya di Lombok Utara Kecamatan Tanjung yang telah mengalami bencana alam berupa gempa yang telah terjadi tahun lalu menyebabkan beberapa fasilitas sekolah PAUD, TK dan RA rusak. Kerusakan fasilitas sekolah ini membuat terhambatnya proses belajar mengajar dan guru korban gempa yang ada disana ketika mengajar hanya menggunakan media atau APE yang seadanya saja. Untuk menanggulangi hal tersebut dilakukanlah penelitian yang berjudul "Pengembangan Alat Permainan Edukatif (APE) Berbasis Lingkungan Untuk Pembelajaran Saintifik Pada Tema Lingkungan Bagi Guru-Guru PAUD Korban Gempa Di Kecamatan Tanjung Lombok Utara". Dimana penelitian ini bertujuan untuk membantu memfasilitasi guru-guru yang berdampak gempa untuk bisa menciptakan APE yang sederhana namun dapat digunakan dalam proses belajar mengajar.

\section{Alat Permainan Edukatif (APE)}

Guslinda dan Kurnia (2018, p.29) berpendapat bahwa Alat Permainan Edukatif (APE) adalah macam-macam peralatan atau sesuatu benda yang dapat dipergunakan untuk bermain. Dimana peralatan atau benda tersebut dapat menstimulasi dan mengembangkan seluruh kemampuan anak. Tedjasaputra (2001, p. 81) Mengungkapkan bahwa alat permainan edukatif adalah alat permainan yang dirancang secara khusus untuk kepentingan pendidikan.

Berdasarkan penjelasan Alat Permainan Edukatif (APE) dapat disimpulkan bahwa APE adalah alat yang sengaja dibuat yang digunakan sebagai media pembelajaran yang dirancang secara khusus untuk membantu kegiatan pembelajaran dan memudahkan pendidik untuk menyampaikan materi yang berkaitan dengan pendidikan serta dapat membantu peserta didik untuk mengembangakan aspek perkembangan yang ada.

\section{Alat Permainan Edukatif (APE) Berbasis Lingkungan}

Alat Permainan Edukatif (APE) Berbasisi Lingkungan adalah suatu alat permainan yang dibuat atau digunakan sebagai media untuk proses belajar mengajar yang bersumber dari lingkungan sekitar. Bahan-bahan dari lingkungan yang dapat digunakan sebagai media dalam proses belajar mengajar yakni seperti kebun binatang, taman bunga, kebun buah jeruk dan lain sebagainya. Sedangkan alat-alat yang digunakan untuk menciptakan sebuah APE dari lingkungan yakni berupa kayu, bambu, pasir, tanah liat dan lain sebagainya. Senada dengan hal tersebut, Lighthart dalam Ramadhan (2018) mengungkapkan bahwa bahan pembelajaran dari lingkungan dikelompokkan dalam tiga kategori yaitu: (1) Lingkungan alam sebagai bahan mentah; (2) Lingkungan produsen 
atau lingkungan pengrajin sebagai pengelola dan penghasil bahan mentah menjadi bahan jadi; (3) Lingkungan masyarakat pengguna bahan jadi yaitu sebagai konsumen.

Adapun yang dimaksud dengan bahan ini dapat saja berupa tanaman, tanah, batu-batuan, kebun, sungai dan ladang, pengrajin kayu, rotan dan pasar atau toko sebagai pusat jual beli bahanbahan jadi tersebut.

\section{Pengertian Pembelajaran Saintifik}

Rusman (2017, p.422) mengungkapkan bahwa pendekatan saintifik merupakan sebuah pendekatan pembelajaran yang menekankan pada aktivitas siswa melalui kegiatan mengamati, menanya, menalar, mencoba dan membuat jejaring pada kegiatan pembelajaran disekolah. Pendekatan saintifik merupakan pendekatan pembelajaran yang memberi kesempatan kepada siswa secara luas untuk melakukan eksplorasi dan elaborasi materi yang dipelajarai, disamping itu memberikan kesempatan kepada peserta didik untuk mengektualisasikan kemampuannya melalui kegiatan pembelajaran yang telah dirancang oleh guru.

Sedangkan dalam Kurikulum 2013 PAUD, menyatakan bahwa pelaksanaan pembelajaran untuk tingkat pendidikan anak usia dini digunakan pembelajaran tematik dengan menggunakan pendekatan saintifik. Permendikbud (2013-c, p. 9) menjelaskan bahwa, Kurkulum 2013 menekankan pada dimensi pedagogik moderen dalam pembelajaran, yaitu menggunakan pendekatan ilmiah meliputi mengamati, menanya, mengumpulkan informasi atau mencoba, mengasosiasikan atau menalar, dan mengkomunikasikan (Fithriyyati \& Maryani, 2018; Satrianawati \& Fu, 2019).

Berdasarkan pengertian pembelajaran saintifik tersebut dapat disimpulkan bahwa pembelajaran saintifik adalah pembelajaran dimana semua kegiatan pembelajaran yang dilakukan terfokus pada anak. Anaklah yang lebih banyak melakukan kegiatan dan lebih aktif sehingga nantinya anak mampu melakukan beberapa proses pembelajaran yakni mengamati apa saja yang dipelajari, kemudian menanyakan apa yang telah diamati, mengumpulkan informasi yang didapatkan, menalar informasi dan anak mampu mengkomunikasikan informasi yang didapatkan kepada orang lain.

\section{Tema Pembelajaran}

Suryana (2016, p. 247) menyatakan bahwa tema merupakan alat atau wadah untuk mengenalkan berbagai konsep kepada peserta didik secara utuh. Dalam pembelajaran, tema diberikan dengan maksud menyatukan isi kurikulum dalam satu kesatuan yang utuh, memperkaya perbendaharaan bahasa peserta didik. Dan membuat pembelajaran lebih bermakna. Penggunaan tema dimaksudkan agar peserta didik mampu mengenal berbagai konsep secara mudah dan jelas.

Latif (2013, p.48) mengungkapkan bahwa tema yang merupakan sebuah pokok pikiran disampaikan melalui aliran TFT (term, fact, and principle). Term merupakan informasi umum yang bisa didapatkan anak melalui pengalaman, orang dewasa atau guru, dan teman. Informasi yang diberikan atau dialirkan kepada anak hendaklah merupakan keadaan atau peristiwa yang merupakan kenyataan atau sesuatu hal yang benar-benar ada atau terjadi ( fact), dan sesuatu yang benar dan menjadi pokok dasar berpikir atau bertindak (principle).

Dari pengertian tema tersebut dapat disimpulkan bahwa tema adalah suatu topik yang menjadi bahan pembicaraan atau ide seseorang yang dibahas dalam suatu kegiatan pembelajarn. Tema-tema tersebut dapat ditentukan dan disesuaikan dengan pengetahuan peserta didik.

Tema lingkungan adalah tema yang membahas tentang lingkungan yang dekat dengan anak seperti lingkungan keluarga, lingkungan sekolah dan lingkungan masyarakat. Dalam tema lingkungan keluarga yang dapat dijelaskan berkaitan dengan lingkungan yang ada di keluarga seperti anggota keluarga, tugas anggota keluarga, bagian rumah dan lain sebagainya. Lingkungan sekolah yang dapat dijelaskan yakni berkaitan dengan hal-hal yang ada disekolah seperti bangunan sekolah, fasilitas sekolah, anggota yang ada disekolah (teman,guru penjaga sekolah dan lain sebagainya), aturan yang ada di sekolah. Sedangkan lingkungan masyarakat yakni hal-hal yang ada dimasyarakat seperti anggota masyarakat, profesi yang ada di masyarakat, dan lain sebagainya.

\section{METODE}

Penelitian ini dilaksanakan di Kecamatan Tanjung Kabupaten Lombok Utara pada bulan Januari sampai dengan Bulan Mei tahun 2019. Dalam penelitian ini metode yang digunakan yakni metode penelitian tindakan (action research). Penelitian action research adalah penelitian yang digunakan 
untuk menghasilkan produk tertentu yang disesuaikan dengan kebutuhan masyarakat terutama pada sekolah-sekolah yang berdampak gempa. Penelitian ini dimaksudkan untuk memudahan dan membantu para guru-guru korban gempa dalam mengatasi kegiatan pembelajaran dengan pembuatan APE yang berasal dari lingkungan yang ada disekitar. Penelitian dan pengembangan yang dilakukan adalah untuk mnghasilkan produk berupa Alat Permainan Edukati (APE) yang disesuaikan dengan tema lingkungan.

Adapun populasi dan sampel pada penelitian ini adalah seluruh guru yang ada di kecamatan Tanjung yang berjumlah 151 orang terdiri dari 6 laki-laki dan 145 perempuan. Sedangkan sampel dari penelitian ini yakni $20 \%$ dari jumlah populasi yang ada yang akan dipilih secara random dari 151 guru korban gempa yang ada di kecamatan Tanjung Kabupaten Lombok Utara. Sehingga sampel dari penelitian ini sebanyak 30 orang guru.

Selain itu, untuk membantu proses penelitian digunakanlah metode pengumpulan data. Adapun metode pengumpulan data dalam penelitian ini yakni berupa angket, fokus group diskusi (FGD), dan dokumen.

Angket atau kuesioner merupakan alat pengumpulan data yang memuat sejumlah pertanyaan atau pernyataan yang harus dijawab oleh subjek penelitian. Pertanyaan ini dapat berbentuk terbuka dan juga berbentuk tertutup, pada angket terbuka responden diberikan keleluasaan untuk memberikan tanggapan sesuai dengan persepsi masing-masing, sementara angket tertutup peneliti menyiapkan pertanyaan atau pernyataan tertulis yang telah ada pilihan jawabannya. Dalam penelitian ini angket digunakan untuk mengumpulkan data tentang APE berbasis lingkungan yang bertemakan lingkungan, bentuk APE, dan jenis APE yang dapat dikembangkan dan kelompok APE untuk pembelajaran saintifik.

Sedangkan, Fokus Group Diskusi (FGD) digunakan untuk mengungkapkan permaknaan dari suatu kelompok berdasarkan hasil diskusi yang terpusat pada suatu kelompok berdasarkan hasil diskusi yang terpusat pada suatu permasalahan tertentu. Dalam penelitian ini FGD digunakan untuk mengumpulkan data tentang model atau cara pengembangan APE yang dilakukan, bentuk-bentuk APE dan kelompok APE untuk pembelajaran saintifik. Dan dokumen merupakan sumber data yang digunakan untuk melengkapi penelitian, baik berupa sumber tertulis, film, gambar (foto), dan karyakarya monumental. Dalam penelitian ini dokumen yang menjadi data penelitian adalah hasil karya responden berupa APE dan foto dari APE yang dihasilkan.

Dari hasil penelitian yang telah didapatkan kemudian dianalisi untuk mendapatkan sebuah data. Sehingga untuk mendapatkan data yang lengkap, digunakanlah teknik analisis data kualitatif, yaitu dengan melakukan analisis secara langsung hasil APE yang telah dibuat guru-guru korban gempa di kecamatan Tanjung dengan menganalisis berdasarkan bentuk-bentuk APE yang dapat dikembangkan untuk pembelajaran saintifik pada tema lingkungan, dan mengelompokkan APE yang dapat digunakan untuk pembelajaran saintifik. Sedangkan data hasil pengisian angket kemudian dianalisis dengan menggunakan rumus persentase yakni:

$$
\mathrm{P}=\frac{\mathrm{f}}{\mathrm{n}} \times 100 \%
$$

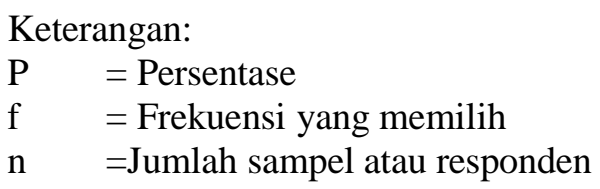

\section{HASIL DAN PEMBAHASAN}

Dari penelitian yang telah dilakukan, hasil penelitian yang telah didapatkan yakni terbentuknya model untuk pengembangan APE, adanya bentuk-bentuk APE yang dikembangkan, dan kelompokkelompok APE yang digunakan untuk pembelajaran saintifik pada tema lingkungan bagi guru PAUD korban Gempa di Kecamatan Tanjung Kabupaten Lombok Utara. Model penelitian ini yakni terbentuknya model pengembangan alat permainan edukatif (APE) berbasis lingkungan untuk pembelajaran saintifik pada tema lingkungan beberapa tahapan model pengembangan yakni identifikasi sumber bahan pembuatan APE berbasis lingkungan untuk pembelajaran saintifik pada tema lingkungan dimana hasilnya dapat diketahuai dari hasil pengisian angket yang diisi oleh 38 guru dimana sumber bahan yang paling banyak disetujui yakni lidi dan stik eskrim sebanyak 97,37\% dan paling sedikit sebanyak $18,42 \%$ yakni aluminium; penglompokkan bahan pembuatan APE berbasis 
lingkungan untuk pembelajaran saintifik pada tema lingkungan dikelompokkan menjadi tiga jenis bahan yakni bahan tersedia dari alam, bahan pabrik dan bahn limbah padat; mengembangkan APE berdasarkan pengelompokkan, dan tercipta APE untuk pembelajaran saintifik pada tema lingkungan.

Bentuk-bentuk APE yang dihasilkan dari penelitian ini yakni APE yang dapat dikembangkan dalam pembelajaran saintifik pada tema lingkungan bagi guru PAUD korban Gempa di Kecamatan Tanjung Kabupaten Lombok Utara yakni bentuk miniatur rumah, bentuk perahu, bentuk mobilmobilan, bentuk orang-orangan dari pelepah pisang, kertas dan kardus bekas, bentuk ikandari kerta origami dan bentuk pohon angka dari ranting pohon kering dan angka berbentuk buah apel yang diberi tulisan angka. Dan kelompok- kelompok APE yang digunakan untuk pembelajaran saintifik pada tema lingkungan bagi guru PAUD korban Gempa di Kecamatan Tanjung Kabupaten Lombok Utara berdasarkan APE yang telah dibuat guru yakni dibagi menjadi dua kelompok APE dengan jenis main peran mikro dan jenis main pembangunan.

\section{SIMPULAN}

Berdasarkan pemaparan yang telah dipaparkanpeneliti diatas maka kesimpulan yang dapat diambil ialah: Model pengembangan alat permainan edukatif (APE) berbasis lingkungan untuk pembelajaran saintifik pada tema lingkungan bagi guru PAUD korban Gempa di Kecamatan Tanjung Kabupaten Lombok Utara dapat dilakukan dengan empat model pengembangan yakni identifikasi sumber bahan pembuatan APE berbasis lingkungan untuk pembelajaran saintifik pada tema lingkungan, pengelompokkan bahan pembuatan APE berbasis lingkungan untuk pembelajaran saintifik pada tema lingkungan, mengembangkan APE berdasarkan pengelompokkan, dan tercipta APE untuk pembelajaran saintifik pada tema lingkungan.

Bentuk-bentuk APE yang dapat dikembangkan dalam pembelajaran saintifik pada tema lingkungan bagi guru PAUD korban Gempa di Kecamatan Tanjung Kabupaten Lombok Utara yakni bentuk miniatur rumah, bentuk perahu, bentuk mobil-mobilan, bentuk orang-orangan dari pelepah pisang, kertas dan kardus bekas, bentuk ikan dari kerta origami dan bentuk pohon angka dari ranting pohon kering dan angka berbentuk buah apel yang diberi tulisan angka.

Kelompok-kelompok APE yang digunakan untuk pembelajaran saintifik pada tema lingkungan bagi guru PAUD korban Gempa di Kecamatan Tanjung Kabupaten Lombok Utara berdasarkan APE yang telah dibuat guru yakni dibagi menjadi dua kelompok APE dengan jenis main peran mikro dan jenis main pembangunan.

\section{DAFTAR PUSTAKA}

Ariesta, R. (2009). Alat permainan edukatif lingkungan sekitar untuk anak usia 0-1 tahun. Bandung: PT Sandiarta Sukses

Fithriyyati, N., \& Maryani, I. (2018). Science lesson plan evaluation for 7th grade secondary school: A learning process reflection. Psychology, Evaluation, and Technology in Educational Research, 1(1), 9-18. doi:http://dx.doi.org/10.33292/petier.v1i1.17

Guslinda \& Kurnia, R. (2018). Media pembelajaran anak usia dini. Surabaya: CV. Jakad Publishing

Latif, M. (2013). Orientasi baru pendidikan anak usia dini. Jakarta: Kencana

Mulyatiningsih, E. (2014). Metode penelitian terapan bidang pendidikan. Bandung: Alfabeta

Ramadhan, S. Z. N. (2018). Pengaruh aktivitas bermain menggunakan bahan alam terhadap kemampuan mengklasifikasi benda pada anak usia 5-6 tahun. Skripsi. Universitas Lampung

Rusman. (2017). Belajar dan pembelajaran berorientasi standar proses pendidikan. Jakarat: Kencana

Satrianawati, S., \& Fu, W. (2019). Education for sustainable development (ESD) in Indonesia: A Conceptual framework. International Journal of Education and Learning, I(1 (2019)), 42-49. doi:https://doi.org/10.31763/ijele.v1i1.33

Sugiyono. (2014). Metode penelitian pendidikan pendekatan kuantitatif, kualitatif, dan R\&D. Bandung: Alfabeta. 
Baik Nilawati Astini, Nurhasanah, Hayatun Nupus

Suryana, D. (2016). Pendidikan anak usia dini stimulasi dan aspek perkembangan anak. Jakarta: Kencana

Susanto, A. (2015). Bimbingan dan konseling di taman kanak-kanak. Jakarta: KENCANA Tedjasaputra, M. S. (2001). Bermain, mainan dan permainan. Jakarta: PT Grasindo

Yaumi, M., \& Mujono, D. (2016). Action research: Teori, model \& aplikasi. Jakarta: Kencan 